\title{
PEMODELAN JUMLAH KUNJUNGAN WISATAWAN MANCANEGARA DI BATAM DENGAN MENGGUNAKAN ARIMA DAN REGRESI TIME SERIES
}

\section{MODELLING FOREIGN TOURIST ARRIVAL IN BATAM USING ARIMA AND TIME SERIES REGRESSION}

\author{
Ely Kurniawati ${ }^{1}$, One Yantri ${ }^{2}$ \\ ${ }^{1,2}$ (Prodi Akuntansi, Fakultas Ekonomi, Universitas Batam, Indonesia) \\ 'elykurniawati@univbatam.ac.id, ${ }^{2}$ oneyantri@univbatam.ac.id
}

\begin{abstract}
Abstrak
Sektor pariwisata memberikan kontribusi yang signifikan terhadap perekonomian Indonesia, yaitu dilihat dari Dampak kepariwisataan terhadap Produk Domestik Bruto (PDB) nasional di tahun 2015 sebesar 4,23\% dari PDB nasional. Demikian juga Batam dinilai memiliki potensi pengembangan sektor ini dikarenakan letak geografisnya yang strategis, yaitu berdekatan dengan negara Singapura dan Malaysia. Berdasarkan Kementrian Kepariwisataan, salah satu sasaran dalam pengembangan pariwisata di Indonesia adalah meningkatnya jumlah kunjungan wisatawan mancanegara, dengan indikator kinerja utama berupa variabel jumlah wisatawan mancanegara yang berkunjung. Sehingga Informasi mengenai prediksi jumlah wisatawan mancanegara yang berkunjung ke Batam dapat bermanfaat untuk memberikan informasi tambahan mengenai pengembangan sektor ini.Berdasarkan analisis awal, diketahui bahwa data memiliki kecenderungan tren dan pola musiman meningkat setiap bulan Desember. Pemodelan dengan pendekatan ARIMA dan Regresi Time Series dapat digunakan pada serial data dengan kecenderungan tren dan musiman. Dalam melakukan analisis, data dibagi ke dalam 2 bagian yaitu data training dan testing kemudian dilakukan pemodelan dengan ARIMA dan Regresi Time Series. Selanjutnya masing-masing model terbaik dilakukan pengecekan asumsi residual dan dihitung nilai MAPE dan RMSE nya. Berdasarkan kedua nilai tersebut, Regresi Time Series menunjukkan nilai terendah dibanding model ARIMA sehingga dipilih Regresi Time Series sebagai model terbaik.
\end{abstract}

Kata Kunci Time Series, Wisman, ARIMA, Regresi Time Series

\begin{abstract}
Tourism has a significant contribution to Indonesia economic condition. The impact of the tourism sector to Gross Domestic Product (GDP) in 2015 is 4,23\% of the total National GDP. Due to its strategic location near Singapore and Malaysia, Batam has a potential development of this sector. One of a key indicator in developing the tourism sector is the number of foreign tourist visitors. Thus information about this variable is necessary for predicting the number of visitors. Based on preliminary analysis, it is shown that the number of foreign tourist visitors tends to increase by time and there is the detection of a seasonal effect in December every year. Time series regression and ARIMA are part of time series method that can be applied in a series of data that is showing trend and seasonal effect. The data is split into training and testing data then modelled using ARIMA and Time Series Regression. After checking its residual assumptions, RMSE and MAPE value is calculated. Based on RMSE and MAPE value, Time series regression is better in modeling both training and testing data.
\end{abstract}

Keywords Time Series, Wisman, ARIMA, Time Series Regression

\section{PENDAHULUAN}

Prediksi jumlah wisatawan mancanegara yang berkunjung ke Batam dapat bermanfaat untuk memberikan informasi tambahan mengenai pengembangan sektor ini. Prediksi dilakukan menggunakan analisis regresi time series serta membandingkan tingkat akurasinya terhadap pendekatan ARIMA. Kedua metode ini dipilih berdasarkan pertimbangan bahwa penelitian ini diharapkan sebagai awalan dalam melihat data wisman di kota Batam untuk selanjutnya dieksplorasi dengan pendekatan lainnya. Selain itu juga didasarkan pada 
simpulan bahwa suatu model time series yang kompleks tidak selalu menghasilkan ramalan yang lebih akurat dibandingkan dengan pendekatan yang lebih sederhana (Makridakis, 2000). Pendekatan time series yang paling popular dan sering dipakai dalam melakukan peramalan adalah model ARIMA sebagaimana yang dilakukan Rukini dkk. (2015) mengenai Peramalan Jumlah Kunjungan Wisman ke Bali. Hasil peramalan yang diperoleh menunjukkan bahwa jumlah wisman pada tahun 2019 berada di bawah target yang ditetapkan, sehingga hal ini merupakan informasi yang penting sehubungan dengan usaha yang harus dilakukan oleh kementerian terkait. Akan tetapi dalam penelitian ini tidak dieksplorasi mengenai tingkat akurasi peramalannya, dan tidak dibandingkan dengan pendekatan metode lain. Penelitian lain mengenai peramalan tingkat kunjungan wisman ke Indonesia dilakukan oleh Maulana (2014). Dalam penelitian tersebut, dilakukan peramalan dengan pendekatan metode regresi (pola linear dan kuadratik) serta rata-rata bergerak (n-3). Ketiga pendekatan tersebut dilihat akurasinya dengan menggunakan indikator MAD, MAPE dan MSE. Data yang digunakan adalah data keseluruhan kunjungan ke Indonesia, sehingga meliputi banyak wilayah dengan berbagai karakteristik.

Metode regresi time series dengan variasi kalender merupakan metode peramalan time series dengan menambahkan variabel dummy yang bersesuaian. Pendekatan variasi kalender dilakukan dalam penelitian yang dilakukan Lee dan Suhartono (2010) untuk meramalkan data penjualan berdasarkan efek Ramadhan. Dalam hal ini variabel dummy yang digunakan adalah hari ramadhan yang selalu berubah setiap tahunnya sehingga tidak dapat terdeteksi oleh faktor musiman. Dalam penelitian ini digunakan dummy hari libur di Singapura dan Malaysia yang diduga memiliki potensi yang besar sebagai wisman di Batam.

Berdasarkan uraian di atas, penelitian ini dilakukan untuk melakukan peramalan jumlah wisman yang berkunjung ke Batam dengan memilih model terbaik dari kedua pendekatan yang digunakan yaitu model regresi time series dan ARIMA. Pemilihan model terbaik didasarkan pada akurasi ramalan data testing dengan kriteria MAPE dan RMSE.

\section{METODOLOGI}

\section{Sumber data dan identifikasi variabel}

Sumber data yang digunakan dalam penelitian ini adalah data jumlah kedatangan wisatawan mancanegara yang diunduh dari website BPS. Berdasarkan penjelasan dalam website BPS, definisi wisatawan mancanegara sesuai dengan rekomendasi United Nation World Tourism Organization (UNWTO) adalah setiap orang yang melakukan perjalanan ke 
suatu negara di luar negara tempat tinggalnya, kurang dari satu tahun, didorong oleh suatu tujuan utama (bisnis, berlibur, atau tujuan pribadi lainnya), selain untuk bekerja dengan penduduk negara yang dikunjungi.

\section{Metode Analisis Data}

Sebelum dilakukan analisis data sesuai dengan tujuan penelitian, dilakukan analisis data awal, yang meliputi :

1. Melakukan identifikasi pola data dengan melakukan analisis eksplorasi data yang meliputi :

a. Perhitungan statistika deskriptif sehingga dapat diketahui ukuran pemusatan dan penyebaran data.

b. Membuat time series plot untuk mengetahui pola data apakah terdapat tren linear, kemungkinan adanya pola musiman ataupun pola lainnya.

2. Pemodelan regresi time series

a. Membagi data menjadi 2 bagian yaitu in sample dan out sample.

b. Meregresikan variabel waktu terhadap variabel jumlah wisman di Batam dengan menambahkan dummy 12 bulan yaitu Januari sampai Desember pada masing-masing bagian.

c. Menguji signifikansi parameter regresi.

d. Melakukan analisis residual model regresi time series, yaitu residual harus white noise dan berdistribusi normal.

3. Pemodelan dengan metode ARIMA

a. Membagi data menjadi 2 bagian yaitu training dan testing.

b. Melakukan identifikasi data dengan plot ACF dan PACF.

c. Melakukan estimasi parameter model yang mungkin berdasarkan plot ACF dan PACF, kemudian memilih model terbaik.

d. Melakukan analisis residual model ARIMA, yaitu residual harus white noise dan berdistribusi normal.

4. Perhitungan tingkat akurasi masing-masing model peramalan dan pemilihan model terbaik

a. Melakukan perhitungan RMSE (Root Mean Square Error) dan MAPE (Mean Absolute Percentage Error) pada masing-masing data in sample dan out sample dan masing-masing model peramalan. 
b. Memilih model terbaik berdasarkan RMSE/MAPE terkecil dan mempertimbangkan uji diagnostik terhadap residual.

\section{PEMBAHASAN}

Tahap paling awal dalam melakukan analisis terhadap data serial adalah melakukan identifikasi pola data dengan membuat tren dari waktu ke waktu (time series plot). Pada gambar 4.1 di bawah ini dapat dilihat bahwa data kunjungan wisatawan mancanegara (wisman) memiliki tren dan menunjukkan adanya pola musiman.

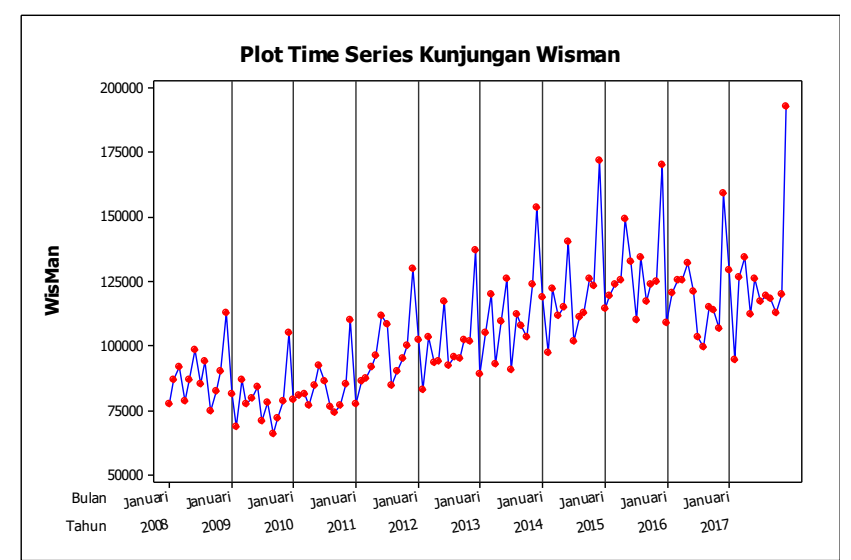

\section{Gambar 1 Plot Time Series Jumlah Wisman di Batam}

\section{Analisis Time Series dengan pendekatan ARIMA}

Berdasarkan plot time series pada gambar 1 di atas, bisa dilihat bahwa terdapat kecenderungan tren meningkat pada jumlah kunjungan wisatawan mancanegara di Batam. Dari pola yang ada menunjukkan bahwa terdapat kondisi tidak stasioner dalam varians maupun rata-rata.

Pengujian Box-Cox pada Tabel 1 berikut ini menunjukkan bahwa rounded value sebesar -1 dengan lower $C L$ sebesar -1,85 dan upper $C L$ sebesar -0,12. Data tersebut semakin menguatkan dugaan bahwa data yang dimiliki belum stasioner dalam varians, sehingga jenis

transformasi yang tepat untuk data tersebut adalah pangkat $(-1)$ atau $\frac{1}{\lambda}$. Pengujian ulang dilakukan terhadap data yang sudah ditransformasi untuk mengkonfirmasi nilai rounded value sebesar -1 . 
Tabel 1 Transformasi Box-Cox pada Variabel Jumlah Kunjungan Wisatawan

\begin{tabular}{lllll}
\hline Transformasi & Estimate & Lower CL & Upper CL & $\begin{array}{l}\text { Rounded } \\
\text { Value }\end{array}$ \\
\hline Sebelum & $-0,94$ & $-1,85$ & $-0,12$ & $-1,00$ \\
Sesudah & 0,94 & 0,12 & 1,85 & 1,00 \\
\hline
\end{tabular}

Data yang telah ditransformasi, selanjutnya dilihat apakah sudah stasioner dalam ratarata dengan melihat pola pada plot ACF dan PACF. Plot tersebut dapat dilihat pada Gambar 2 berikut ini.
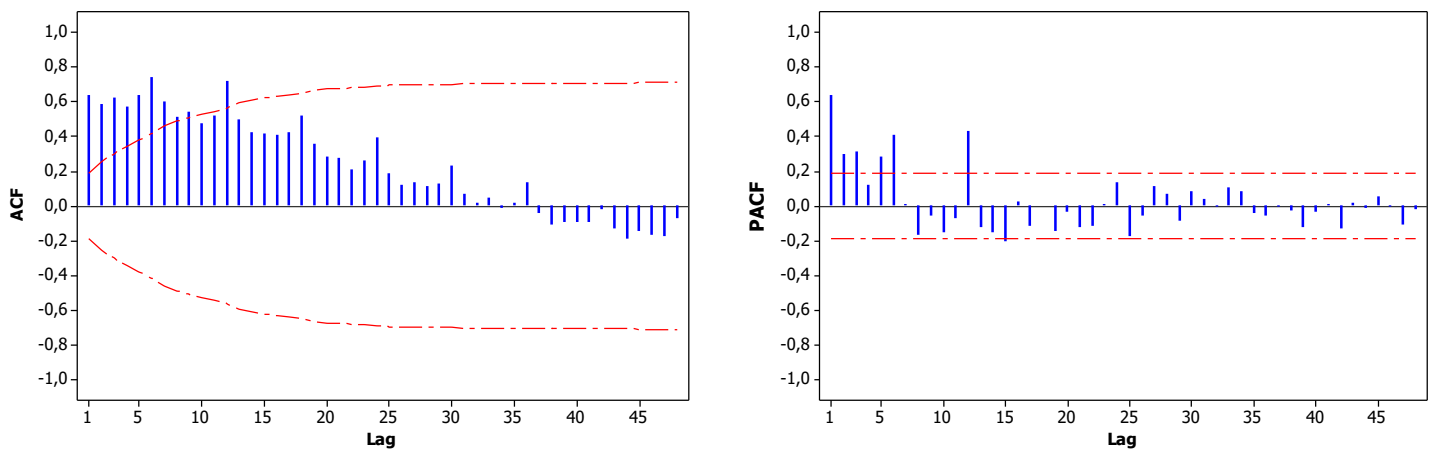

Gambar 2 (a) Plot ACF dan (b) Plot PACF Variabel Jumlah Kunjungan Wisatawan

Pola data pada lag-lag dalam plot di atas belum menunjukkan kondisi stasioner dalam rata-rata. Selanjutnya dilakukan proses differencing 1 pada data tersebut dan diperoleh plot ACF dan PACF sebagaimana Gambar 3.
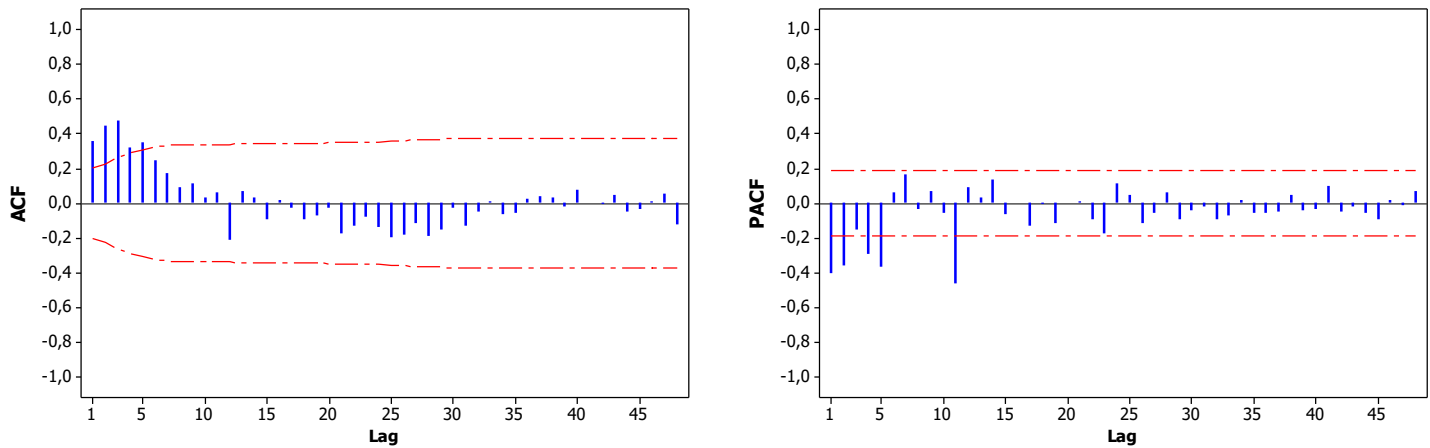

\section{Gambar 3 (a) Plot ACF dan (b) Plot PACF Variabel Jumlah Kunjungan Wisatawan Setelah Differencing Satu $(d=1)$}

Kondisi lag-lag pada gambar di atas menunjukkan beberapa nilai yang menunjukkan pola musiman, sehingga coba dilakukan differencing dengan pola musiman $(D=1 ; S=12)$. Hasil differencing satu dapat dilihat dalam Gambar 4 berikut ini. 

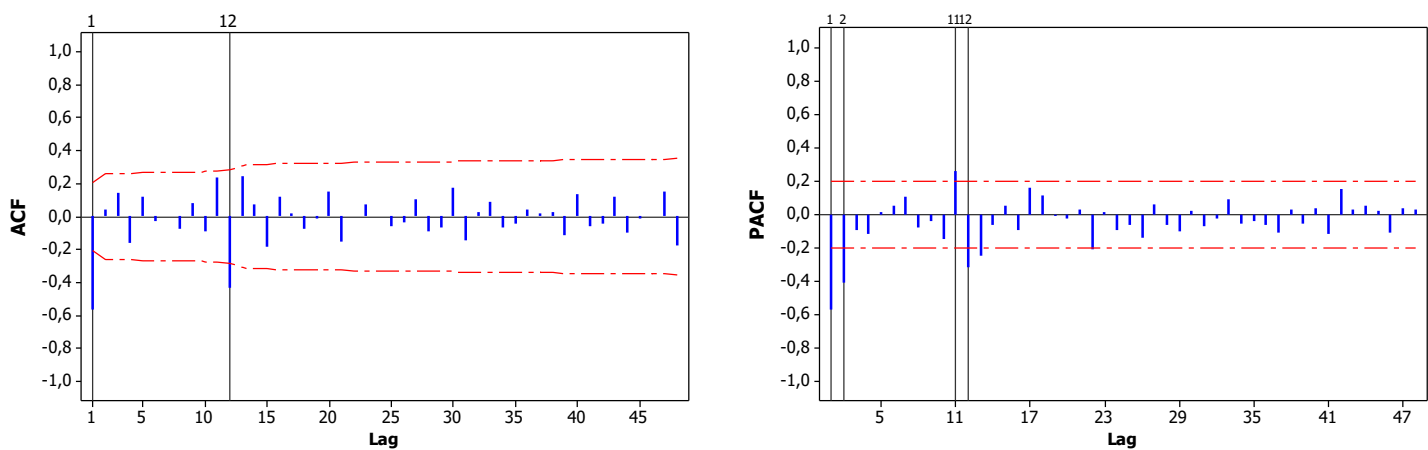

Gambar 4 (a) Plot ACF dan (b) Plot PACF Variabel Jumlah Kunjungan Wisatawan $(\mathrm{d}=1 ; \mathrm{D}=1 ; \mathrm{s}=12)$

Dari Gambar 4 di atas dapat dilihat bahwa sebagian besar lag sudah berada dalam limit. Beberapa lag yang masih keluar adalah lag-lag musiman, sehingga data dapat dikatakan telah stasioner. Model ARIMA yang sesuai dengan pola lag pada Gambar 4 di atas antara lain adalah ARIMA $(0,1,1)(0,1,1)^{12}$, ARIMA $(0,1,2)(0,1,0)^{12}$, dan ARIMA $(2,1,0)(0,1,1)^{12}$.

Pengujian ketiga model ARIMA tersebut pada variabel jumlah kunjungan wisatawan mancanegara dan estimasi parameternya diberikan dalam Tabel 2 berikut ini.

Tabel 2 Estimasi dan Uji Signifikansi Parameter untuk Model ARIMA Jumlah Kunjungan Wisatawan

\begin{tabular}{ccrr}
\hline Model & Parameter & Estimasi & p-value \\
\hline \multirow{2}{*}{ ARIMA $(0,1,1)(0,1,1)^{12}$} & $\theta_{1}$ & 0,7097 & 0,000 \\
& $\Theta_{1}$ & 0,6684 & 0,000 \\
\hline \multirow{2}{*}{ ARIMA $(0,1,2)(0,1,0)^{12}$} & $\theta_{1}$ & 0,9072 & 0,000 \\
& $\theta_{2}$ & $-0,2985$ & 0,003 \\
ARIMA $(2,1,0)(0,1,1)^{12}$ & $\phi_{1}$ & $-0,7799$ & 0,000 \\
& $\phi_{2}$ & $-0,4149$ & 0,000 \\
& $\Theta_{1}$ & 0,5814 & 0,000 \\
\hline
\end{tabular}

Berdasarkan Tabel 2 di atas, Model ARIMA yang ditetapkan telah memiliki parameter yang signifikan. Tahap berikutnya adalah melakukan pemeriksaan residual white noise dan residual berdistribusi normal. Hasil pemeriksaan white noise untuk model ARIMA $(0,1,1)(0,1,1)^{12}$, ARIMA $(0,1,2)(0,1,0)^{12}$, dan ARIMA $(2,1,0)(0,1,1)^{12}$ diberikan dalam Tabel 3 berikut ini. 
Tabel 3 Hasil Uji White Noise Residual Model ARIMA Jumlah Kunjungan Wisatawan

\begin{tabular}{crrrr}
\hline Model & Lag & $\chi^{2}$ hitung & \multicolumn{1}{c}{$\boldsymbol{d} \boldsymbol{f}$} & p-value \\
\hline & 12 & 9,2 & 10 & 0,515 \\
ARIMA $(0,1,1)(0,1,1)^{12}$ & 24 & 19,1 & 22 & 0,641 \\
& 36 & 28,3 & 34 & 0,745 \\
& 48 & 37,9 & 46 & 0,796 \\
\hline \multirow{2}{*}{ ARIMA $(0,1,2)(0,1,0)^{12}$} & 12 & 22,3 & 10 & 0,014 \\
& 24 & 35,1 & 22 & 0,038 \\
& 36 & 46,1 & 34 & 0,081 \\
ARIMA $(2,1,0)(0,1,1)^{12}$ & 48 & 59,9 & 46 & 0,082 \\
\hline & 12 & 8,0 & 9 & 0,532 \\
& 24 & 18,1 & 21 & 0,644 \\
& 36 & 25,0 & 33 & 0,841 \\
& 48 & 37,7 & 45 & 0,772 \\
\hline
\end{tabular}

Dalam uji white noise digunakan hipotesis awal bahwa antar residual adalah independen. Sehingga dengan taraf signifikansi 0,05 maka residual dikatakan sudah white noise jika nilai $P$-value lebih besar dari 0,05. Berdasarkan Tabel 3 di atas, model ARIMA $(0,1,1)(0,1,1)^{12}$ dan ARIMA $(2,1,0)(0,1,1)^{12}$ telah memiliki residual yang white noise. Tahap berikutnya adalah menguji normalitas dari residual kedua model tersebut dan hasilnya disajikan dalam Tabel 4 berikut ini.

Tabel 4 Hasil Uji Normalitas Residual Model ARIMA Jumlah Kunjungan Wisatawan

\begin{tabular}{ccc}
\hline Model & $\begin{array}{c}\text { Statistik } \\
\text { Komogorov-Smirnov }\end{array}$ & $\boldsymbol{p}$-value \\
\hline ARIMA $(0,1,1)(0,1,1)^{12}$ & 0,061 & $>0,150$ \\
\hline ARIMA $(2,1,0)(0,1,1)^{12}$ & 0,048 & $>0,150$ \\
\hline
\end{tabular}

Kedua model menunjukkan bahwa $P$-value lebih dari taraf signifikansi 0,05, sehingga disimpulkan berdistribusi Normal. Untuk pemilihan model terbaik, berdasarkan prinsip parsimony, dipilih model ARIMA $(0,1,1)(0,1,1)^{12}$ karena memiliki parameter yang lebih sedikit. 


\section{Analisis Time Series dengan pendekatan Regresi Time Series dan Regresi Dummy}

Pemodelan data kunjungan wisatawan mancanegara dengan menggunakan regresi time series dan regresi dummy merupakan gabungan dari pemodelan regresi variabel Yt yang merupakan jumlah kunjungan wisatawan mancanegara di Batam, terhadap variabel $\mathrm{t}$, waktu dan dummy bulan dari Januari sampai Desember dengan harapan agar bisa menangkap pola musiman dalam bulan-bulan tersebut.

Hasil analisis regresi terhadap t dan dummy bulan diperoleh hasil persamaan regresi sebagai berikut ini:

$Y(t)=108823+502 t-38812$ Bulan-1_1 - 39557 Bulan-1_2 - 29533 Bulan-1_3 37584 Bulan-1_4 - 30106 Bulan-1_5 - 22091 Bulan-1_6 - 41909 Bulan-1_7 - 38256 Bulan1_8 - 42474 Bulan-1_9 - 38285 Bulan-1_10 - 34479 Bulan-1_11

Adapun hasil pengujian signifikansi koefisien diberikan dalam Tabel 5.

Tabel 5 Hasil Uji Signifikansi Parameter Regresi-1

\begin{tabular}{cccc}
\hline Prediktor & Koefisien & $\boldsymbol{T}$ & $\boldsymbol{p}$-value \\
\hline Constant & 108823 & 28,50 & 0,000 \\
T & 502,15 & 16,17 & 0,000 \\
Bulan-1_1 & -38812 & $-8,21$ & 0,000 \\
Bulan-1_2 & -39557 & $-8,38$ & 0,000 \\
Bulan-1_3 & -29533 & $-6,26$ & 0,000 \\
Bulan-1_4 & -37584 & $-7,96$ & 0,000 \\
Bulan-1_5 & -30106 & $-6,38$ & 0,000 \\
Bulan-1_6 & -22091 & $-4,68$ & 0,000 \\
Bulan-1_7 & -41909 & $-8,89$ & 0,000 \\
Bulan-1_8 & -38256 & $-8,12$ & 0,000 \\
Bulan-1_9 & -42474 & $-9,01$ & 0,000 \\
Bulan-1_10 & -38285 & $-8,12$ & 0,000 \\
Bulan-1_11 & -34479 & $-7,32$ & 0,000 \\
\hline
\end{tabular}

Berdasarkan pemeriksaan koefisien dan model secara keseluruhan, persamaan sudah signifikan secara statistik. Selanjutnya dilakukan pemeriksaan terhadap residual model, dan ditemukan bahwa residual masih menghadapi masalah residual independen sebagaimana dilihat pada gambar berikut ini. 


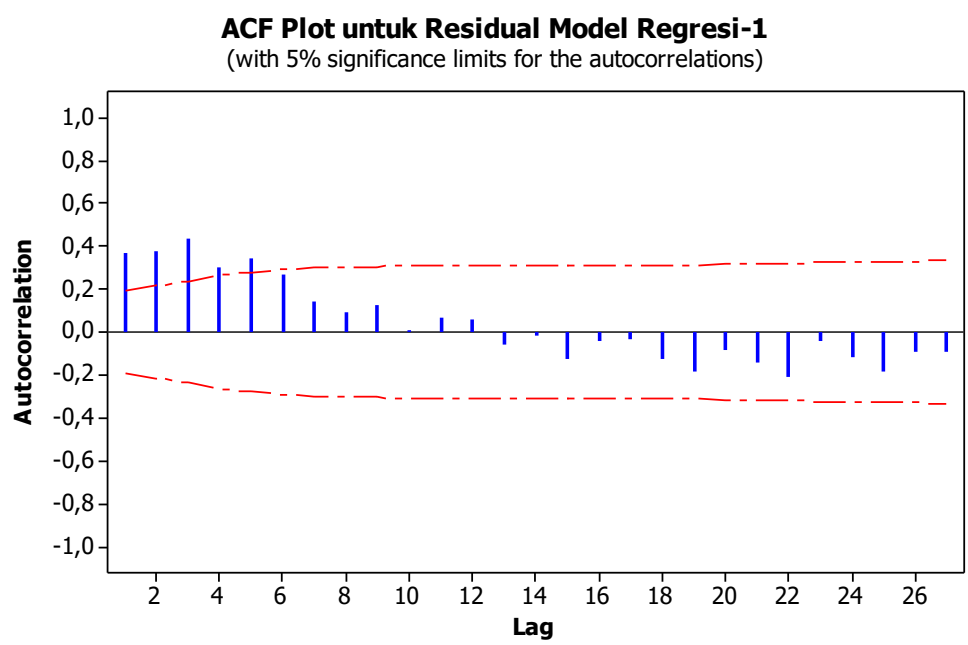

Gambar 5 Plot ACF untuk model regresi -1

Berdasarkan plot ACF residual pada gambar 5 dilakukan perbaikan terhadap model regresi time series dengan menambahkan pengamatan ke $(t-1),(t-2)$ dan $(t-3)$. Kriteria tersebut dibuat berdasarkan pengamatan terhadap lag yang keluar dari batam plot ACF residual. Hasil pemodelan ulang dengan menambahkan tiga variabel tersebut diberikan dalam persamaan berikut ini,

$$
\begin{aligned}
Y(t) & =61241+161 t-47402 \text { Bulan-1_1 - } 53330 \text { Bulan-1_2 - } 44445 \text { Bulan-1_3 } \\
& -39099 \text { Bulan-1_4 - } 32631 \text { Bulan-1_5 - } 27197 \text { Bulan-1_6 - } 46942 \text { Bulan-1_7 } \\
& -45175 \text { Bulan-1_8 }-48164 \text { Bulan-1_9 - } 37468 \text { Bulan-1_10 } \\
& -34503 \text { Bulan-1_11 }+0,224 \text { Y1 }(t-2)+0,126 \text { Y1 }(t-1)+0,343 \text { Y1 }(t-3)
\end{aligned}
$$

Tabel berikut ini memberikan hasil uji signifikansi parameter regresi. Ditemukan bahwa parameter pada variabel $\mathrm{Y}(\mathrm{t}-1)$ tidak memberikan hasil yang signifikan secara statistik. Selanjutnya variabel tersebut dikeluarkan dan dilakukan analisis regresi ulang.

Tabel 6 Hasil Uji Signifikansi Parameter Regresi-2

\begin{tabular}{cccc}
\hline Prediktor & Koefisien & $\boldsymbol{T}$ & $\boldsymbol{p}$-value \\
\hline Constant & 61241 & 7,06 & 0,000 \\
\hline t & 161,35 & 2,42 & 0,018 \\
\hline Bulan-1_1 & -47402 & $-9,09$ & 0,000 \\
\hline Bulan-1_2 & -53330 & $-9,39$ & 0,000 \\
\hline Bulan-1_3 & -44445 & $-7,19$ & 0,000 \\
\hline Bulan-1_4 & -39099 & $-9,72$ & 0,000 \\
\hline Bulan-1_5 & -32631 & $-7,95$ & 0,000 \\
\hline Bulan-1_6 & -27197 & $-6,53$ & 0,000 \\
\hline Bulan-1_7 & -46942 & $-11,32$ & 0,000 \\
\hline Bulan-1_8 & -45175 & $-9,93$ & 0,000 \\
\hline
\end{tabular}




\begin{tabular}{cccc}
\hline Bulan-1_9 & -48164 & $-10,50$ & 0,000 \\
\hline Bulan-1_10 & -37468 & $-9,23$ & 0,000 \\
\hline Bulan-1_11 & -34503 & $-8,52$ & 0,000 \\
\hline$Y 1(t-1)$ & 0,12553 & 1,26 & 0,210 \\
\hline Y1(t-2) & 0,22441 & 2,27 & 0,025 \\
\hline Y1(t-3) & 0,3434 & 3,41 & 0,001 \\
\hline
\end{tabular}

Persamaan regresi yang dihasilkan dari analisis regresi tahap ke-3 adalah sebagai berikut,

$$
\begin{aligned}
Y(t) & =65739+189 t-43423 \text { Bulan-1_1 - } 55635 \text { Bulan-1_2 - } 46976 \text { Bulan-1_3 } \\
& -38574 \text { Bulan-1_4 - } 33407 \text { Bulan-1_5 - } 27172 \text { Bulan-1_6 - } 45834 \text { Bulan-1_7 } \\
& -47101 \text { Bulan-1_8 - } 49317 \text { Bulan-1_9 - } 38493 \text { Bulan-1_10 } \\
& -35012 \text { Bulan-1_11 }+0,256 \text { Y }(t-2)+0,382 Y(t-3)
\end{aligned}
$$

Seluruh parameter model regresi-3 telah memenuhi kriteria dan signifikan secara statistik sebagaimana ditunjukkan oleh tabel 7, sehingga model persamaan dapat diterima. Selanjutnya dilakukan pengujian terhadap residual, meliputi asumsi identik, independen dan berdistribusi normal (IIDN).

Tabel 7 Hasil Uji Signifikansi Parameter Regresi-3

\begin{tabular}{cccc}
\hline Prediktor & Koefisien & $\boldsymbol{T}$ & $\boldsymbol{p}$-value \\
\hline Constant & 65739 & 8,29 & 0,000 \\
T & 189,49 & 3,00 & 0,003 \\
Bulan-1_1 & -43423 & $-10,42$ & 0,000 \\
Bulan-1_2 & -55635 & $-10,31$ & 0,000 \\
Bulan-1_3 & -46976 & $-8,01$ & 0,000 \\
Bulan-1_4 & -38574 & $-9,61$ & 0,000 \\
Bulan-1_5 & -33407 & $-8,20$ & 0,000 \\
Bulan-1_6 & -27172 & $-6,51$ & 0,000 \\
Bulan-1_7 & -45834 & $-11,28$ & 0,000 \\
Bulan-1_8 & -47101 & $-10,96$ & 0,000 \\
Bulan-1_9 & -49317 & $-10,93$ & 0,000 \\
Bulan-1_10 & -38493 & $-9,65$ & 0,000 \\
Bulan-1_11 & -35012 & $-8,66$ & 0,000 \\
Y(t-2) & 0,25609 & 2,67 & 0,009 \\
Y(t-3) & 0,38243 & 3,98 & 0,000 \\
\hline
\end{tabular}



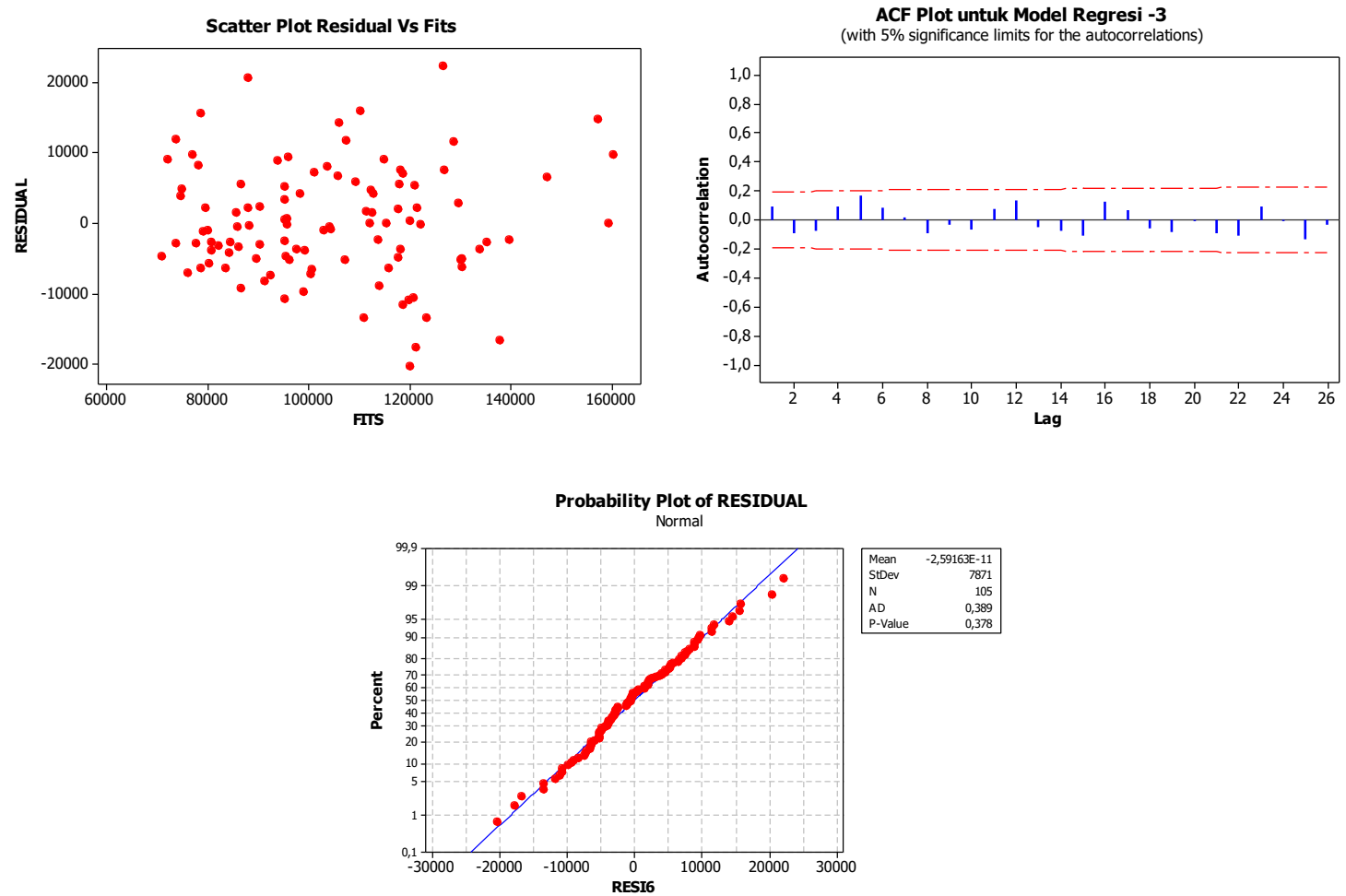

\section{Gambar 6 (a) Scatter Plot Residual vs Fits, (b) Plot ACF Residual dan (c) Normal Probability Plot Residual}

Hasil pengujian asumsi residual menunjukkan residual memenuhi kriteria IIDN sebagaimana ditunjukkan gambar 6. Berdasarkan scatter plot antara residual dan fit menunjukkan pola yang acak yang merupakan indikasi residual identik. Plot ACF residual menunjukkan bahwa semua lag berada dalam batas yang menunjukkan bahwa residual independen terhadap waktu. Pengujian terakhir terhadap asumsi normalitas menunjukkan bahwa residual signifikan berdistribusi normal.

\section{Pemilihan Model Peramalan Terbaik}

Pada bagian sebelumnya sudah dibahas beberapa metode untuk melakukan peramalan time series. Dalam sub bagian ini akan dilakukan pemilihan model terbaik yang direkomendasikan untuk digunakan dalam meramalkan jumlah wisatawan mancanegara di Batam. Kriteria pemilihan model terbaik didasarkan pada nilai RMSE (Root Mean Square Error) dan MAPE (Mean Absolute Percentage Error) yang terkecil. 
Tabel 8 Nilai RMSE dan MAPE Masing-masing Metode

\begin{tabular}{ccccc}
\hline Metode & \multicolumn{2}{c}{ RMSE } & \multicolumn{2}{c}{ MAPE } \\
& Training & Testing & Training & Testing \\
& & & & \\
\hline ARIMA & 9933,37 & 15470,9 & 7,5317 & 9,5941 \\
Regresi Time & 7833,43 & 13955,1 & 5,9929 & 9,2149 \\
Series & & & & \\
& & & & \\
\hline
\end{tabular}

Tabel 8 di atas menunjukkan bahwa pendekatan Regresi Time Series terbaik dalam semua pendekatan baik itu untuk data training maupun data testing. Dugaan awal penggunaan metode ini untuk meramalkan jumlah wisatawan mancanegara di Batam dapat dibuktikan berdasarkan analisis data penelitian ini. Hal ini dikarenakan dalam regresi time series, baik elemen waktu (t), maupun elemen musiman (dummy bulan) dimasukkan dalam model sehingga dapat menjelaskan kondisi pola data kunjungan wisatawan mancanegara di Batam yang memiliki unsur tren dan musiman. Semakin diperjelas oleh plot berikut ini.

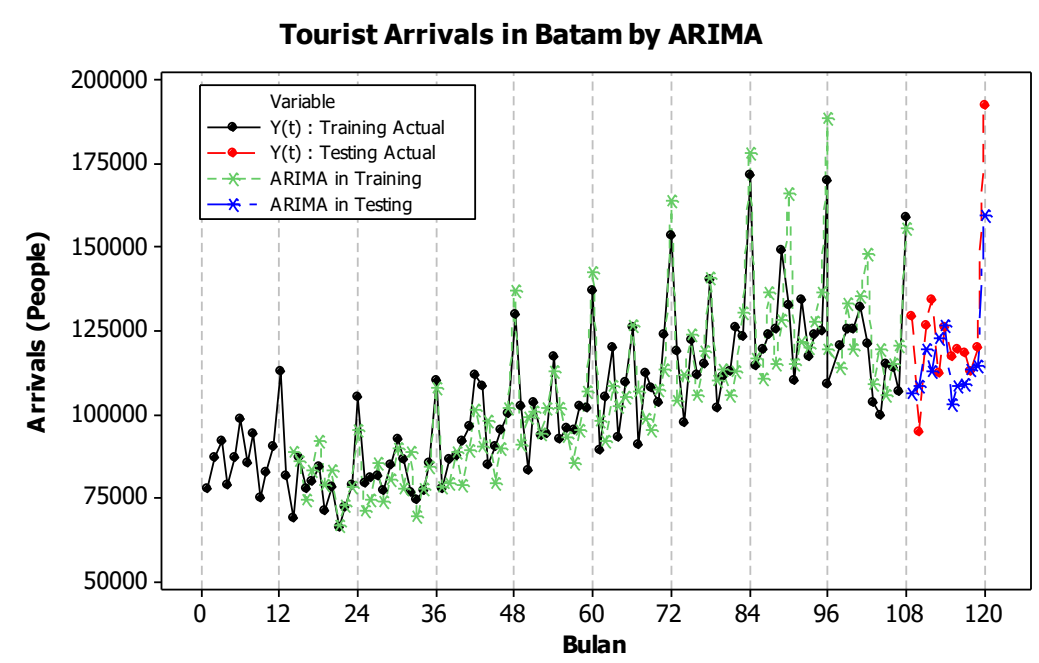

(a) 


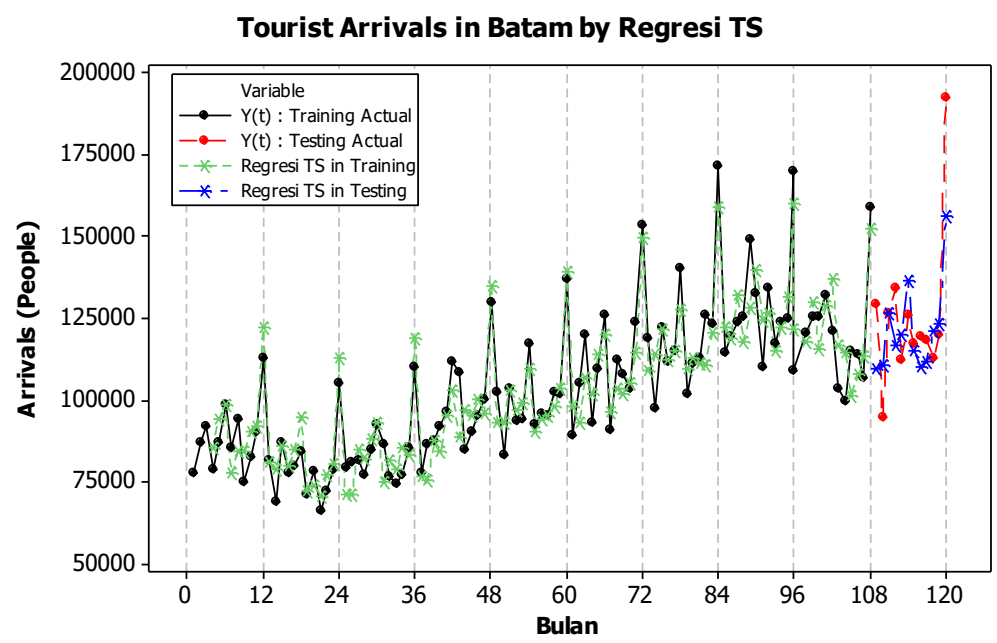

(b)

Gambar 7 Hasil Pemodelan dengan metode (a) Regresi Time Series dan (b) ARIMA

\section{KESIMPULAN DAN SARAN}

\section{Kesimpulan}

Setelah dilakukan analisis data, maka kesimpulan yang dapat diambil adalah sebagai berikut :

1. Model ARIMA terbaik yang sesuai adalah ARIMA $(0,1,1)(0,1,1)^{12}$, setelah dilakukan pengujian signifikansi dan asumsi residual.

2. Model regresi time series yang sesuai adalah yang melibatkan variabel waktu $(t)$, variabel dummy bulan (Januari sampai Desember) dan Pengamatan ke $(t-2)$ dan $(t-3)$. Pengujian terhadap asumsi residual juga dapat terpenuhi.

3. Setelah dilakukan perhitungan RMSE dan MAPE, model terbaik diberikan oleh Regresi Time Series.

\section{Saran}

1. Untuk meramalkan jumlah wisatawan mancanegara, dapat digunakan pendekatan regresi time series karena melibatkan elemen tren dan musiman yang terdapat pada pola data jumlah kunjungan wisatawan mancanegara.

2. Bagi penelitian lanjutan, dapat dicoba menggunakan metode time series non linear.

\section{REFERENSI}

Box, G., Jenkins, G., \& Reinsel, G. 2008.Time Series Analysis Forecasting and Control.Prentice-Hall Inc., New Jersey. 
Chen, R. J. C, Bloomfield, P., Fu, J. S. 2003.An Evaluation of Alternative Forecaasting Methods to Recreation Visitation.Journal of Leisure Research Vol. 35 No.4, pp. 441 454.

Draper, N. dan Smith, H. 1992. Analisis Regresi terapan (edisi kedua). Jakarta: Gramedia Pustaka Utama.

Kalekar, P.S. 2004.Time series forecasting using Holt-Winters exponential smoothing, Kanwal Rekhi School of Information Technology.

Lee, M.H., Suhartono. 2010. calendar variation model based on ARIMAX for forecasting sales data with Ramadhan effect.Proceeding of RCSS'10 hal. 349-361.

Makridakis. 2000.The M3 Competition: result, conclusion andimplication.International Journal of Forecasting $16 \mathrm{Hal}$. 451-476.

Makridakis, S.G., Wheelwright, S.C., Hyndman, R. J. 1998.Forecasting : Methods and Application, John Wiley \& Sons Inc., New York.

Maulana, Addin. 2014.Penerapan Metode Proyeksi Kecenderungan dengan Regresi dan RataRata Bergerak Studi Kasus Peramalan Tingkat Kunjungan Wisatawan Mancanegara ke Indonesia hingga 2025, Jurnal Kepariwisataan Indonesia Vol.9 No.4.

Rukini, Arini, P.S., Nawangsih, E. 2015.Peramalan Jumlah Kunjungan Wisatawan Mancanegara (Wisman) ke Bali tahun 2019: Metode ARIMA.Jurnal Ekonomi Kuantitatif Terapan Vol.8 No.2.

Wei, W. W. S. 2006.Time Series Analysis, Univariate and Multivariate Methods. Pearson.

- (2016) , Laporan Akuntabilitas Kinerja Kementerian Pariwisata (LAKIP Kemenpar) tahun 2015. 